\title{
On the margins: young men's mundane experiences of austerity in English coastal towns
}

Linda McDowell, Carl Bonner-Thompson and Anna Harris

School of Geography and the Environment, University of Oxford, South Parks Road, Oxford OX1 33QY

This paper explores the everyday experiences of young white working-class men living in coastal towns badly affected by austerity programmes implemented in the UK since 2010. The lives and aspirations of marginal young men seldom feature in studies of the effects of economic crisis and austerity. These men are positioned at the intersection of several rhetorical constructions with contradictory and ambivalent affects. They are expected, and still expect, to become wage earners and providers, largely through their own efforts and self- improvement. A rhetoric of social mobility disguises structural inequality, producing a false promise of hope or 'cruel optimism' about future prospects. Simultaneously, young working- class men, especially those without employment, typically are constructed as a threat to (middle class) society, difficult or dangerous, and authors of their own disadvantage. We explore how young men, without regular work and often lacking family support, talk about everyday experiences, social relationships, feelings and emotions and hopes for the future in coastal towns with a particular place in the national imaginary.

Keywords: austerity, structures of feeling, optimism, symbolic violence, coastal towns, young men

\section{Introduction}

Twelve years after the global financial crisis and ten years since the start of a programme of fiscal austerity in the UK, there is now is a substantial inter-disciplinary body of work, unpacking the uneven impact of austerity policies and growing economic insecurity. Multiple dimensions of the aftermath of the crisis at different scales have been examined, including individual and household behaviour. We build on this work in an exploration of the everyday experiences of austerity for young men from working-class backgrounds, born in the 1990s. Growing up in austere times, these men are at particular risk of material hardship, as a consequence of austerity and longer-term changing labour market prospects for men. We focus on their everyday lives, experiences and aspirations through an analytical lens based on the combination of a number of concepts including structures of feeling, cruel optimism and symbolic violence, providing a way of bringing together discourses that position young working-class men as both authors of their own lives and undeserving. We document the co-existence of hope, resignation and self-blame as young men struggle to survive without secure employment. These men may blame themselves for their current 
predicament, bored by everyday circumstances, distracted, sometimes by drink, drugs and smallscale violence that exacerbates their marginality, and yet remain optimistic about the future.

The argument is in several parts. First, we provide some context, outlining recent austerity policies in the UK and current scholarship exploring their impact. We turn next to the specificities of coastal towns, and the atmospheres or structures of feeling that are both part of their location in the national imaginary and the consequences of austerity. We then outline our theoretical position, followed by a discussion of the findings. Finally, we suggest some lines of future work.

\section{Austerity and everyday lives}

In the decade and more since the banking crisis in 2008 and the introduction of a range of fiscal policies to reduce deficits in government spending, the term austerity has become increasingly common in political rhetoric and academic and policy research. The focus here is the UK where there is mounting evidence of the continuing impact of austerity on the poorest sections of society, despite claims that austerity is 'over' (Kentish 2018). Real wages declined for the poorest sections of the working population by approximately 10 percent between 2008 and 2018 (Corlett et al 2018) and families and individuals most at risk of poverty have been subjected to cuts in income and in a range of social and welfare support services, including those for young people. Government support for youth services has been severely cut (from f1billion in 2008-09 to $f 388$ million in 2016-17: a cut of $62 \%)$. Budgets for public services such as parks, swimming pools and libraries have also been cut, reducing places where young people may congregate at little or no financial cost (Campbell et al 2019; Hughes et al 2014).

The term austerity captures not only the political justification for cuts in government spending and the material consequences for individuals, households and families but also the everyday effects of living with uncertainty. Austerity bites (O'Hara 2014), doing violence to people's sense of themselves (Cooper and Whyte 2017) inducing fear and distrust, as well as humiliation among, for example, the growing number of people forced to rely on food banks (Strong 2019). 
While care, compassion, pity and solidarity are also evident, documented, for example, among middle-class volunteers and professionals involved in social service delivery (Clayton et al 2015), for individuals 'at the sharp end', austerity has negative consequences, affecting confidence, self-belief and hopes for the future. As Hitchen (2016:102) argued, austerity 'is lived and felt in everyday life ... as a series of atmospheres ... that shape everyday practices and future imaginaries', deepening insecurity.

A growing body of research, drawing on different theoretical traditions including feminist scholarship (Hall 2019a), geo-social psychology (Stenning 2020) and non-representational theory (Hitchen 2019), has explored the experiences and feelings engendered by austerity. The everyday lives of diverse individuals and groups in British towns and cities have been documented, as austerity reshapes and reduces opportunities. Loyalty, shame, anger and boredom, hope, loss, and regret have been identified as emotional responses (Hall 2017; 2019a and b; Harris et al 2018; Horton 2016; Horton and Kraftl 2009; Jupp 2017).Growing material hardship has increased termed 'family fragility' (Hall 2019b) with negative consequences for social networks, emotional life and aspirations for the future. As family support mechanisms are fractured, working-class households find it increasingly hard to provide both material and emotional support for workless adult children (Hardgrove et al 2015; McDowell and Harris 2018; Power and Hall 2018). Parents may feel guilty about the lack of support they are able to offer their children, who in turn may resent their parents.

The dominant empirical focus of this scholarship on austerity has been on the household, the work of women as providers (Raynor 2017), or those with particular needs for support where cuts in services have reduced their independence. The impact of austerity on people with disabilities (Runswick-Cole and Goodley 2015), for example, or families in housing need has been explored (Harris et al 2018). These studies reveal complexities and contradictions in the ways in which cuts are administered and implemented, as well as how emotional reactions to austerity affect people's 
sense of themselves and hopes for the future. Here, we shift the focus onto young men living in coastal towns: a group and places seldom featured in debates about the consequences of austerity.

\section{Life on the coastal margins}

Austerity has not only a widespread impact on the lives of the least affluent and most disadvantaged but also takes an uneven geographical form. Cuts in budgets and services have fallen hardest on British towns and cities with a sizeable proportion of the population with low incomes, often dependent on welfare services, and unable to purchase replacement support in the market. Previous work on the effects of austerity has tended to focus on larger towns and cities, typically in the north, or on inner London boroughs. However, coastal resorts in England recently have been identified as amongst the most deprived parts of the country, with rising levels of poverty and homelessness (Corfe 2017; House of Lords 2019). These towns, literally marginal, are also increasingly socially and economically marginal, neglected by policy and holiday makers alike. Despite a small recent increase in the number of British families choosing to holiday at home, as income levels among the least affluent fail to return to pre-crisis levels, the long-term decline of traditional seaside holidays has continued (Gale 2005; Rickey and Houghton 2009) with a serious impact on the 'atmosphere' of these towns. Here we gesture to Marshallian notions of 'industrial atmosphere' that captured the feelings of confidence and prosperity producing a virtuous circle of expansion in the heyday of industrial growth in British cities. The same term was re-employed in analyses of the economic success of the 'Third Italy' in the 1970s and 1980s. However, we turn it on its head to capture the dispiriting atmosphere permeating the narratives of decline currently characterising coastal resorts. Outside the holiday season when temporary job opportunities and renovated holiday accommodation produce an optimistic façade, long term decline, homelessness, drug addiction and rising numbers of dilapidated properties from the era of Victorian expansion (Ward 2015) are serious issues for local authorities with reduced budgets. Summer visitors may swell the long-term resident population, but population decline, especially the out-migration of young people for further education and secure employment, is a major underlying trend. These towns have 
always been among those with low average incomes, high rates of seasonal unemployment, and poverty of opportunities exacerbated by geographical isolation. Young people with aspirations for higher education and professional credentials have little option but to move elsewhere (Crowley and Cominetti 2014). Less-skilled members of the working -class are literally 'left behind'. Despite insecure and seasonal employment, state support of all kinds, including financial benefits, has been cut to force the workless into the labour market: a policy disguised under the tag 'making work pay' with particularly pernicious effects in towns with seasonal labour markets.

We focused on young men in these towns for a number of reasons. Their visible presence 'hanging out' in public spaces, with little to do, exacerbates the atmosphere of isolation and desolation, especially in winter months, as other residents avoid spaces regarded as insalubrious or threatening (McDowell and Harris 2018). A second reason lay in arguments about the impact of austerity on future aspirations. Are young men growing up in the second decade of the $21^{\text {st }}$ century optimistic about their future? Are their lives significantly different from those of men who came of age in earlier decades? There is now a substantial literature about the impact of longer-term labour market change in the west for young men without skills, documenting the consequences of the growth in part-time, insecure, temporary and precarious employment. Forms of precarious attachment to the world of waged work, however, have become increasingly significant in the decade of austerity (PrassI 2018). In the UK, the relative disadvantage of young working-class men has deepened and changed its form. As numerous studies revealed, many jobs in the service sector depend on the performance of deference, an attribute at odds with hegemonic versions of workingclass masculinity (Ilan 2015; Nixon 2017), exacerbating the relative disadvantage of young men with few personal skills or qualifications compared to younger and older women. Recent labour market changes may be more ambiguous. Expanding opportunities including driving cars for hire, cycle couriers and food delivery riders in the 'gig' economy, are more easily coded masculine and so perhaps attractive to young men with few credentials other than bodily strength and persistence (Bloodworth 2018; Day 2016). However, for the most disadvantaged among this group, the need to 
own, at a minimum, a smart phone and a bicycle may disqualify them, reinforcing their exclusion and leaving them moving between periods of casual employment and worklessness (McDowell 2019).

The extent to which the term precarious or precarity differs from austerity was a further stimulus to our work. In an interesting discussion of austerity as a rhetorical construction or story to convince the public of the need to 'tighten belts', Raynor (2017) notes parallels between the 1940s and the 2010s in the way in which economic policy is compared to a household budget (also a common trope of the Thatcher years). This narrative perhaps makes particular sense to women but also produces wider feelings of solidarity, as the Government continually suggests 'we are all in this together'. Forkert (2017) developed a similar analysis of the rhetorical construction of austerity, suggesting its emphasis on combatting the extravagance of the years of New Labour spending (19972010) is almost religious in its insistence on austerity as a way to redemption. While these constructions may have resonance with the life experiences or knowledge of history of some of the UK population, they seem unlikely to make sense to young people born in 1990s, coming of age when widespread cuts and 'reforms' formed the background to their lives.

Whether or not the young men were talked to used or understood the term austerity, the consequence of cuts since 2010 was to deepen their disadvantage as their parents or other carers were less able to offer support. The support of mothers, in particular, providing both material and emotional support to their sons, is crucial for young men from working- class backgrounds leaving education and searching for employment (Hardgrove et al 2015). This was the group of economically marginal men to whom we talked.

\section{Atmospheres, structures of feeling, cruel optimism and symbolic violence}

Our theoretical position is based on the juxtaposition of notions of atmospheres and structures of feeling as a way to capture shared emotions in a town with Berlant's (2011) concept 'cruel optimism' and Bourdieu's (1984) of symbolic violence. The term 'atmospheres' has a history as a useful concept to capture a general spirit of hope or hopelessness pervading a place, class or social group. 
'Austerity is felt as a series of atmospheres that envelope and condition everyday moments and spaces' (Hitchin 2018:103). This definition is close to the concept 'structures of feeling' developed by the literary critic Raymond Williams (1980): the same term used by Berlant in her analysis of the consequences of the current political regime. Rather than psychological theorisations of 'affect' to capture emotions, feelings and atmospheres that characterise post social-democratic times, Berlant grounds her work in a return to Williams' arguments about how societies agree on social and political conventions as lived experiences of feelings, how certain views of the future come to seem feasible, others not. This notion is useful, we argue, at the local as well as a national scale. We use the term atmospheres or structures of feeling in way that is more akin to the old geographical tradition of the spirit of a place, in this instance the particular atmosphere that pervades marginal coastal resorts in England, while also exploring Berlant's arguments about the cruel optimism structuring everyday life.

Berlant's book Cruel Optimism (2011) is an incisive analysis of the decline of social democratic ideals in the USA since the 1980s, as promises of a better life, economic security, uncontested forms of personal intimacy and beliefs in intergenerational social mobility recede. She explores the consequences for everyday life, for a sense of self and optimistic beliefs in the future. Despite the austere socio-economic climate, people's hope for a good life and a belief in social mobility act to maintain legitimacy in conditions of economic decline. Through a rhetoric of individual responsibility, people are instructed to take their fate into their own hands, assured that hard work in a meritocratic society will bring success (Grimshaw and Rubery 2012; Littler 2017). Berlant shows how this belief in success through hard work largely sustains the poor in their commitment to democratic ideals and hope for a more optimistic future: a belief that she argues is cruel and unattainable. 'A relation of cruel optimism exists when something you desire is actually an obstacle to your flourishing' (Berlant 2011:1). Retaining a belief in permanent work, for example, may act as barrier to seeking other forms of employment. Cruel forms of optimism in terms of workplace success are disseminated through varying mechanisms such as self-help magazines and 
courses, as well as the demand by the British state that continuous on-line job searches are a requirement for qualifying for financial benefit, despite the lack of jobs in many localities. More widespread discourses of hope are spread through popular media and religious beliefs, as well as through a consumer economy in which the possession of iconic brands are portrayed as symbols of success. The marketing of desire in consumer economies is a potent form of excluding the poor.

Berlant's notion of cruel optimism is particularly appropriate to studies of young people, for whom the hopes of their parents, and their own dreams as they leave childhood, may be cruelly dashed by economic and social austerity. Accounts of young men's feelings and emotions in austere times are not yet common. However, in recent work in Cairo, Pettit (2019) employed Berlant's notion of cruel optimism to explore how relationships between meritocratic beliefs, hope and optimism play out for middle-class young men, stuck without decent work and waiting for better prospects. He documented the ways in which they survived the impasse of insecurity, taking casual jobs below their qualifications while remaining optimistic about the future, hanging out to pass time, spending time and money on various leisure pursuits that helped them maintain a sense of acceptable masculine identity.

While a provocative exploration of cruel optimism, we argue that the disjuncture between hope for a better life through individual effort and blame for failure plays a more significant part in the everyday lives of young working-class men in Britain. Not only are the opportunities available in a large city such as Cairo and small coastal resort in England significantly different, but working-class young men in Britain are regarded as unworthy and dangerous, constructed as unruly and disreputable. There is long-standing history in the UK of the demonization of working-class men through their rhetorical construction as out of control, overtly sexualised and in need of surveillance, especially in public arenas (Connell 2000; Jones 2011). In the decade of austerity, young people in Britain have been variously described as undeserving 'chavs' (Jones 2011), skivers or scroungers (Morrison 2018; Valentine and Harris 2014), as scum, yobs and morons by the press (Tyler 2013). 
This form of stigmatization, in which the relatively blameless majority of insecure and workless youth are included in the rhetorical construction as dangerous, is evident in both official and popular practices, from sentencing policies, 'moving on' loitering young people to everyday interactions between the population of British town and cities. Youths on the streets typically are seen as people to be shunned and avoided, suspected as potential disturbers of the peace or as a sobering lesson of what might lie in store if efforts to conform and work hard are not maintained by the respectable members of society (Ilan 2015; McDowell and Harris 2018). Marginalisation of unacceptable 'others' is achieved through both through discourse and attitudes and in Bourdieu's (1984) terms, through a bodily hexis marked as inferior through everyday social and cultural practices. This produces a form of symbolic violence, in which widely accepted and taken-forgranted 'truths', in this case about working-class youths, position dominated groups in a divisive and hierarchical way. These 'truths' are often unquestioned by the dominated group who come to see themselves as less deserving, to blame for their own inferiority, the objects of symbolic violence 'the violence which is exercised upon a social agent with his or her complicity' (Bourdieu and Wacquant 1992: 167). The effect may be that not only are the dominated complicit in their acceptance of 'the natural order of things' but the group on whom symbolic violence is perpetrated may exaggerate the characteristics that exclude them in the first place in the absence of hope, making 'a virtue of necessity' (Bourdieu 1984:96).

Building on Rootham and McDowell's (2017) study of precarious working lives in Swindon in England, we combine these concepts, or rather counterpose Berlant's concept of cruel optimism to Bourdieu's claims of lack of hope inherent in the concept of symbolic violence to explore the atmospheres and everyday experiences of insecurity in coastal towns.

\section{Living on the margins: methods}

The ways in which people respond to changes in their everyday experiences are not easy to capture. The impacts of austerity are neither obvious nor straightforward. Feelings of hope, despair or 
resignation may have multiple origins and consequences, affecting everyday lives in different ways and with different degrees of intensity. They may not be understood as part of a deliberate programme, nor seen as different from what happened before the 2010s. Nevertheless, we hoped that through careful conversations we might capture the feelings and emotions of young men at risk from austerity through an exploration of what might seem like the mundane events of their everyday lives.

We talked to 10 young working- class men in each of three coastal towns in England (Hastings, Southport and South Shields), each with a population of 60,000. They were similar in ranking high on indicators of deprivation, in losing male-dominated employment in the fishing industry, in growing inequality and in visible problems of poverty and homelessness. Rates of youth unemployment in all three places were higher than the national average (11.2\% in December 2018) and are seasonally variable. Participants were identified through leaflet drops and posters, through youth organisations, and visits to 'hang out spots'. All respondents were aged between 18 and 24, the majority under 21 , and they were all white - a deliberate choice as young white working-class men have low levels of participation in post-school education and training, but also reflecting the general population of the towns (over $95 \%$ white). We too are white. Racism towards the respondents was not a significant dimension of analysis, but nor did their whiteness bring privilege. Indeed, the term 'white working-class' carries with it pejorative associations, including moral judgements about lack of effort, and, more widely, a discourse that labels the working class as too loud, too large, generating a visceral dislike among the middle class (Skeggs 2004). This visceral reaction parallels Nayak's (2006) arguments about the embodied spectacular masculinities of white male excess. We use the term white working class to capture this idea of embodied masculinity but as a necessary descriptor, not a judgemental label.

This lack of diversity, a former Schools Commissioner, Liz Sidwell, claimed, in an injudicious interview, has a significant impact on ambitions. 'In a monoculture, in particular in seaside areas and 
coastal areas, they (the white working-class) ... haven't come from a culture where they have got to work. They think there's a more limited range of things they can aspire to' (Vasager 2011). This captures more general attitudes - the atmosphere or structures of feeling - towards the workingclass in these towns, and to unemployed youths in particular.

Interviews took place between October 2017 and January 2019. We opened by asking 'what is it like growing up around here?', followed by exploring recent events, feelings and hopes about the prospects of finding a job, relationships with family and friends and ways of passing time. We did not explicitly introduce the term austerity (nor did any of the 30 men use it) but tried to capture temporal shifts by asking whether life had become more difficult lately, and how it compared to their father's experiences. With permission, each interaction was recorded. We kept notes, made just after each interaction. Our aim was to understand the commonalities and connections between the narratives, as well as the ways in which these men talked about hope, optimism and violence.

Inevitably in interviews the social characteristics and differences between the interlocutors, positioned differently by multiple axes of power, affect the exchange. Whatever the original class background of researchers, our situation as university employees differentiates us from workingclass respondents. Difficult questions must be considered about how to establish an ethical relationship with working-class participants, as well as how to avoid representing them in the ensuing text as victims. Relying on feminist arguments about an ethic of care for others (Caretta and Riano 2016), we endeavoured to treat interviewees with respect, while remaining open to a compassionate but constructively critical account of their lives.

\section{Mundane lives: waiting for something better}

11 of the 30 men were unemployed at the time of the interview, 7 had some form of precarious work; the remainder were enrolled part-time on educational courses. One man was living rough, and a further two were de facto homeless, sofa-surfing with friends or relatives. 11 men were living in a shelter or hostel as a consequence of family breakdown; several had lived on the streets before 
being rehoused. One man lived with foster parents, another with an unrelated couple in a scheme called Shared Lives. The others lived with parents, although this was often difficult and unstable. Many men came from large families living in cramped conditions, exacerbated by problems including addiction, sometimes for both generations.

Several men had personal issues, including dyslexia, epilepsy, autism and unspecified learning difficulties. Many had truanted or been excluded from school, and several had been in trouble with the police. The apparent stability of attending college proved to be a mirage, as most men's attendance was sporadic. They were uninterested in the courses, preferring to spend days on the local streets or in friends' homes.

In each town, the men were waiting, as several suggested, for 'something to turn up', most obviously waged work or a place in a hostel, but also shorter-term opportunities: a loan from a friend, finding something to sell or the chance to buy a cheap mobile phone. They reported a range of emotions when talking about periods of unemployment or homelessness, including feelings of frustration, anxiety, embarrassment, shame, boredom, and depression. Nevertheless, they all believed that eventually they would find employment. As we explore below, they exhibited a paradoxical combination of hope and self-blame, creating for many an impasse in which positive action seemed difficult. Further, as we demonstrate, the current benefit system exacerbates feelings of being trapped. This feeling of powerlessness, of being trapped in an impasse, is common in studies of precarity and austerity (Harris et al 2018).

\section{Stuck in repetitive precarious work}

The feeling of being stuck or trapped, stuckedness as Hage (2008) terms it, presupposes the possibility of mobility, an imaginary future where life is different. For these men that future included waged employment, one of the key correlates of a respectable masculinity (Connell 2000). Holding down a job is seen by society at large and the young men in this study as their key aim, albeit no longer the sort of permanent job that (some of) their fathers had held when younger. They were 
clear-sighted about the specificity of current opportunities in coastal towns - 'there's not much going at this time of year' (Darren, Southport) and even less optimistically 'there is no work around here, really' (the opinion of James in Hastings but echoed more widely). At the time of the conversations (outside the peak tourist season) only 7 of the 30 participants were working for wages, but a belief that they would find work persisted. The majority actively continued to search for employment, often leaving a college place for a short-term opportunity, and so reducing their chance to gain a qualification that might lead to more secure employment. Almost all men had had a series of temporary jobs from the age of 18 and often earlier. Their experience in the labour market consisted of casual employment, usually found through personal contacts, including working for relatives or friends, in jobs seen as appropriately masculine, including labouring and plastering. This belief that hard manual work was more congruent with their idea of an acceptable masculinity led some to reject what they regarded subservient feminised employment, hoping for better prospects than the casual work in shops and cafes that dominated advertised vacancies in each town. Even so, some men had undertaken casual work - in the retail sector, in take-away outlets, stacking supermarket shelves, washing dishes in cafés and pubs. The belief that what one man termed 'real men's work' was worth waiting for is a good example of cruel optimism. Hoping for work in manufacturing, for something conferring the attributes of masculinity, but which no longer existed, if it ever had, in these coastal towns, and turning down 'feminised' employment, he condemned himself to unemployment, reducing future options.

Although most jobs were monotonous, poorly paid and insecure, almost all the men suggested that they enjoyed their limited work experience. Ashley and Kyle, both 18 , had spent the previous summer travelling as casual workers for a peripatetic fairground, erecting and dismantling the rides and living in a container with other young men. 'It was one of the best things I've done in my life' Ashley explained, although he returned to Hastings as he 'missed the coast'. Meanwhile, he was clearing abandoned houses with his brother, while considering applying for work on the night shift in a local supermarket. 'There's not a lot out there, to be honest', but he remained hopeful of 
finding employment, arguing that personal contacts are essential. 'To get on you need to know the right people'. He had made little effort to construct a cv or to fill in application forms: an example of how an optimistic belief was a barrier to the hope of finding work. Nevertheless, Ashley had hopes of 'getting on' and, despite preferring Hastings to elsewhere, at least had some experience of moving away. It was noticeable that all the other men, with the exception of Kyle, despite talking about their town as variously 'depressed', 'a dump', as a 'hopeless place', had never considered leaving. 'Stuckedness' also applies to geographical immobility - staying put in a place that may be depressing but was at least familiar.

One of the interesting paradoxes in the narratives was the combination of unrealistic ambitions with a clear view their impossibility. Several men told us of imaginary futures that included professional employment. Here is Dale, working erecting scaffolding dreamed of a different life:

It isn't really a steady job. It is cash in hand ... but cash in hand's not something you want to be with for the rest of your life ... I wouldn't mind being a PE teacher ... something challenging'.

Adam had a similar ambition - 'I'd like to be a secondary music school-teacher. I think I could teach in a creative way' - but he too lacked the necessary educational qualifications. Their hopes conform to a version of cruel optimism as they prevented them settling into a search for more reliable work congruent with their (lack of) skills. Billy too hoped for a fulfilling job, but was more realistic about his prospects. 'I want to be a football manager, but as you can see I'm not the fittest guy in the world'. He had taken a one-week course and was given an imaginary award 'most likely to be England's manager'. 'Like that's ever gonna happen' he commented bitterly, well aware of the false promise of such courses.

Despite their dreams, these men and others accepted and found some pleasure in the casual jobs they were offered, albeit still hoping for more stable employment. Their narratives combined 
optimism with resignation, yet among the men who found work there was little sign of the weariness or exhaustion revealed in Wilkinson and Ortega-Cortez's (2019) study of young women in their thirties. What was evident, however, was the weariness, indeed almost despair, of men who felt they were trapped by the operation of the benefits system. One of the marked changes in the decade of austerity has been the introduction of a means-tested workfare system of financial benefits: universal credit. The respondents had a clear understanding of the ways in which this system produced a further impasse, trapping them without employment. The operation of the current benefit system, introduced from 2013 onwards, rather than limited full-time opportunities or unrealistic optimism about future prospects, prevented some from achieving their aspirations. As Kegan, among others, explained, the benefits system traps them in idleness by providing an income larger than from casual employment. They remain unemployed and so, lacking experience, find it increasingly difficult to secure any form of work, let alone the secure employment they longed for. Kegan captured this contradiction in his final comment. 'There's no need for me to work, but it's just gonna ruin me life. That doesn't sound right does it? To me it doesn't sound right at all . . I should be working'. Adam summed up the emotional impact of this trap. 'Basically, there's no need to look for work, there's not. Except, what most young males round here don't realise is the mental impact it has on you, like, just waiting for me dole'.

\section{The paradox of self-blame and self-belief}

One of the significant findings that emerged from the narratives was an ambivalence in the attribution of blame for current insecurity. There was an almost complete consensus among the respondents that their failure to hold down a job for long was not their own fault. If they could just find work, they argued, they would stick with it, despite contradictory evidence in their employment histories. However, their self-belief that they would be reliable employees was at odds with their belief that they had been school failure through lack of effort. More than half of the men in each town told us they messed about at school which they now regretted, as it hindered them in the 
search for work. Once they found a job, however, their belief in their own efforts was evident. Losing a job was regarded as the consequence of accidental events or unfair treatment. Kevin, who had had numerous jobs in kitchens, told us 'I never get a job that lasts for some reason. I've always been kicked out the door, after 2 or 3 months'. One employer, he reported, sacked him after an even shorter time 'After a month they said '"sorry, mate, you're gonna have to go"'. Jordan, like others, had confidence in his work ethic but difficult personal interactions led to him losing jobs. Just 21 , he had held a series of labouring jobs over the past four years, although he was not working when he spoke to us.

I've done quite a lot of labouring, like I'm more of a manual grafter. I like to get me hands dirty. ... I've done a bit of roofing, gutter replacements, labouring, cash-in-hand work.

Sacked for absenteeism, he found a job in a warehouse through a friend:

To do with palettes and boxes. ... I loved it, l'd love a job like it again, but I walked out. Issues in the workplace itself with me mate'.

Despite leaving, he was confident in his work ethic, telling us 'they did miss me though, you know what I mean? I put my graft in every day'.

This type of cheerful insouciance and optimistic outlook was common. Despite the majority of men being out of work when we met them, they assumed they would find a job before long. While this is evidence of an adherence to the protestant ethic and the belief that rewards should be earned, it reveals a lack of knowledge of the current labour market circumstances. As casual precarious employment relations become increasingly dominant at the lower end of the market, no amount of effort will ensure regular and work for men like these. Nevertheless, the men in this study continued to hope for better times.

In other studies it has been argued that one consequence of growing precariousness is that some young men make a deliberate decision to withdraw from the labour market (Giazitzoglu 2014), 
choosing not to look for work as a form of passive resistance (Hardgrove et al 2015). Here, however, an optimistic view that what Jordan termed 'putting in his graft' would see them finding work, even if it was casual, insecure and low paid, was common. As Nixon (2017) found in his study of young working-class men, most of them were 'yearning to labour'. Nevertheless, despite their optimism, many of the men were stuck in an impasse: without regular work, short of money, and looking for ways to keep boredom at bay. We turn now to the 'cruel optimism' embedded in leisure activities and consumer goods marketed at young men.

\section{Waiting, coping and cruel distractions}

As already noted stuckedness (Hage 2009) and waiting (Jeffrey 2000, Jononen 2017) are common tropes in research with people who are, for different reasons, insecure or precarious. Boredom is a typical correlate (Anderson 2004; O’Neil 2017). A variety of leisure activities provide ways of coping with boredom, kicking a ball about, playing computer games, drinking or drug taking (Nayak 2006; Roberts 2012). Few of the men in this study had the financial or emotional resources to have an active social life. Inexpensive ways of passing time and waiting, the sort of hanging about on street corners that filled their days, left them anxious or frustrated, while their visibility exacerbated their construction as threatening wastrels.

Most of the men harboured ambitions, thwarted by lack of income, to engage in those 'cruel forms of distraction' (Pettit 2018) that portray a neoliberal version of successful masculinity; watching mainstream films, acquiring a gym-toned body or purchasing life-style commodities. A hair style, cheap versions of iconic garments worn by footballers or musicians for a moment gave them a vison of themselves as successful, or at least as having something in common with other young men. Activities and desires that portray or depend on a hegemonic version of masculine success and hopes for the future that were eluding them are, however, painful as images of successful youthful masculinity in the media and other forms of consumer culture remind them of their relative failure to measure up to these representations. 
Free or low-cost activities were a common way of coping boredom. Jordan speaks for many of the participants when he says 'I hang out, messing about, play a bit of footie, or a bit of playstation, go to the cinema sometimes'. Josh had a similar response: 'I play football with my friends, typical lad things, go out drinking'. Three men mentioned playing computer games, - but agreed with one of them, Billy, that after a while they became 'super boring'. Designating places and people as boring is in itself part of the construction of masculinity (Joelsson 2017) and a way of coping with dissatisfaction. It was also reflected in comments about the towns themselves 'it's boring here out of season' and 'back of beyond here' were remarks made by several men in all three places, and yet they seldom thought of leaving.

Berlant argued that one way of challenging personal powerless is to over-indulge in activities that on the surface seem pleasurable, identifying activities such as over-eating, or hoarding collectable objects as examples. Among young men substance abuse - alcohol and illegal drugs - is a common way of challenging powerless through seeking excitement and taking risks (Ilan 2013). In each town, knowledge of and some involvement with drug-taking was ubiquitous. Such involvement operated as a coping mechanism, and for some an income, but often precipitating trouble with the police. Some men avoided the drug scene; others were actively involved. Here is Josh in South Shields: 'on nights out there's a lot of drug dealers and stuff. I don't really like that crowd'. But almost all the men, including those who avoided the obvious drug scene, took recreational drugs occasionally, some of them harder drugs and a few spoke about involvement in dealing. Some voiced regrets about their involvement, as two men, in their early 20s, explained:

I smoke cannabis quite heavily to forget how I feel about certain things ... I use weed to get rid of my anger. I did get into a few like little gangs and a few drugs here and there, selling weed to make money, wrong things like that but you grow out of it. You look at yourself and think fucking hell, what am I doing? (Jordan) 
Drugs has got me into stupid shit. Now I smoke a bit of weed but nothing else. I don't want to fuck up my life (Dale).

As well as understanding the consequences of their actions, it was evident that the majority had a clear view of how they were regarded by the general public in their home towns. As Chris in Hastings noted 'You get looked at differently on the street. Some people are like "who's the reprobate down the street"?' This view of working-class young men in public spaces as threatening is widely reflected in the local press coverage of vandalism, visible drug use and on-street drinking, as well as in reports of street violence between rival groups of men. These reports and the wider stigmatisation of sections of working-class youths as troublesome exemplify Bourdieu's notion of symbolic violence, in which divisions between the respectable and unacceptable versions of identities, in this case masculinity, are constructed, regulated and maintained. National policy debates and a genre of TV 'realism', sometimes termed poverty porn, also demonise young men and other members of the working class. Faced by disapproval and too often exclusion, one of the responses to symbolic violence discussed by Bourdieu is to exaggerate and so exacerbate the characteristics disapproved of by the majority population. Most of the men, however, as we showed above, form a more clear-sighted view of what is regarded as acceptable, as they became a little older, altering their behaviour in the hope of greater acceptance and its correlate: employment. However, the combination of their unsuccessful school careers, their relative lack of work experience and for many their reputation, whether deserved or not, as disruptive, make their optimism about the future seem a cruel emotion.

\section{Conclusions}

Our contribution here is to add empirical depth to work on the emotional impacts of austerity, by focusing on the lived experiences of a group of men whose lives are seldom visible in work on the socio-economic consequences of austerity (although see Horton 2016; van Lanen 2017). We explored young white working-class men's attitudes, hopes and beliefs, noting expressions of 
optimism in their future prospects, but also self-blame for their current predicament. We documented their experiences of frustration and despair as well as moments of hope and longing, suggesting the extent to which these latter emotions may be seen as cruel or misjudged as these men find themselves in increasingly insecure situations. The study adds to literatures about gender, class, youth and precarious lives in the UK. Focusing on the atmospheres and everyday lives of men growing up in deprived coastal communities we have shown how the intersection of age, class and gender position young men as 'victims' of change. However, our aim has also been to challenge this label, by placing their lives in a theoretical understanding of the coincidence of two dominant discourses. First, the insistence that individual effort will bring success produces a false or cruel optimism among those for whom the prospect of social mobility is out of reach. Paradoxically, this dominant neoliberal ideology is contradicted by a discourse of unacceptability, of unworthiness that constructs sections of the working class, and young men in particular, as undeserving and so excluded from the mainstream by their own lack of effort. What our fieldwork has revealed is the way in which the men with whom we worked simultaneously adhere to versions of both positions. They are optimistic that through their own efforts they will find work, yet blame themselves for earlier failures at school.

Talking to them and seeing how they regarded their lives as casual workers, as despised by others when hanging out in public spaces between periods of exploitative work, and yet retaining a relatively positive view of their future brings into sharp focus the consequences of the ten years of austerity that have succeeded the financial crisis. Anger, listlessness and boredom co-exist with optimism and ambition, and yet overall, these men not only have a clear view of the way in which they are seen by 'respectable' members of society but also of the limited opportunities that face them. It is this clarity that is perhaps the cruellest feature of their lives. Despite the evidence of some optimism about the future, the attitudes of these young men are better captured as a form of resigned realism. Resignation is perhaps a rather dismal corrective to the romanticised versions of unruly resistance to bourgeois values found in earlier research with young men. 
These men do not see themselves as living in a period of crisis - the other term commonly linked to austerity (Castree 2009; Hall 2019a). Instead, their experiences are a continuous part of the longer-term exclusion of a significant proportion of working class. For these men, despite objectively growing up in the aftermath of the global financial crisis, family poverty, and uncertain working lives were the lot of many in their parent's generation too. For them insecurity, rather than crisis, is the norm, not the exception. These men, however, unlike earlier cohorts, are more likely to have experienced periods of homelessness or to have left their parental home altogether. Berlant and Stewart (2019) speculate that an intergenerational divide may opening in which parents, who retain some fragments of optimism and hope for the future, find their millennial offspring, who have resigned themselves to precariousness as life's defining feature, increasingly unintelligible. Unfortunately, it was not possible to explore this speculation as the men in this study refused permission to contact their parents. However, Bessant et al (2017) suggest young people reaching adulthood in the west are a new 'precarious generation'.

A research agenda that continues to unpack the consequences for children and young people growing up as austerity policies affect everyday lives and aspirations remains crucial. Although the notion of stages or transitions is often criticised in youth studies, France (2008) has argued persuasively for a sustained research effort on the consequences of growing up in poverty for young adults. Geographers might usefully turn their attention to intergenerational and longitudinal studies, tracking individuals and households across the life cycle, to uncover the longerterm implications of ten years of austerity and new intersections between class, gender and age, and ethnicity. Revealing the long-term uneven geographic implications for children and young people living in isolated coastal or rural communities, in inner cities or on deprived estates in more affluent towns is also crucial for policy debates. Perhaps even more significant is a deeper understanding of the social and cultural consequences of the resigned realism found among the men to whom we talked. Whether they will have access to resources that will ensure their future economic security as 
well as permit their participation in new political debates, around climate change for example, now being led by school and university students and young adults, is an urgent question.

\section{Acknowledgements}

Thank you to the men who shared their hopes and fears with us and to three referees for their helpful advice that made this a better paper.

\section{Conflict of interest}

There are no conflicts of interest.

\section{Funding}

The research was part supported by the Leverhulme Trust's Emeritus Research Fellowship awarded to Linda McDowell. St John's College Oxford's Small Grants Scheme also contributed towards the travel costs.

\section{ORCHID iD}

Linda McDowell 0001-7888-0886

Carl Bonner-Thompson 0002-1589-6116

\section{References}

Anderson, B. (2004). Time-spilled, space-slowed: how boredom matters. Geoforum 35 (6), 739-54.

Berlant, L. (2011). Cruel Optimism. Durham NC: Duke University Press.

Berlant, L. and Stewart, K. (2019) The Hundreds. Durham NC: Duke University Press.

Bessant, J., Farthing, R and Watts, R. (2017). The Precarious Generation. London: Routledge.

Bloodworth, J. (2018). Hired: Six Months Undercover in Low-wage Britain. London: Atlantic Books.

Bourdieu, P. (1984). Distinction. A Social Critique of the Judgement of Taste. Cambridge,

Massachusetts: Harvard University Press.

Bourdieu, P., \& Wacquant, L. (1992.) An Invitation to Reflexive Sociology. London: Polity Press.

Campbell, D., Haroon, S., \& Butler, P. (2019). Fraying Britain; how the painful and profound effects of austerity are hurting society, The Guardian 9 March, 10-11.

Caretta, M. \& Riano, A. (2016). Feminist participatory methodologies in geography: creating spaces of inclusion. Qualitative Research, 16, 258-266.

Castree, N. (2009). Crisis, continuity and change: neoliberalism, the left and the future of capitalism.

Antipode, 41, 185-213. 
Clayton, J., Donovan, C. \& Merchant, J. (2015). Emotions of austerity: care and commitment in public service delivery in the North East of England. Emotions, Space and Society, 14, 24-32.

Connell, R. (2000). The men and the Boys. Cambridge: Polity.

Cooper, V. \& Whyte, D. (2017). The violence of austerity. London: Pluto.

Corfe, S. (2017). Living on the Edge: Britain's Coastal Communities. London: Social Market Foundation.

Corlett, A., Bangham, G. \& Finch, D. (2018). The Living Standards Outlook 2018. London: Resolution Foundation.

Crowley, L. \& Cominetti, N. (2014). The geography of youth unemployment: a route map for change. University of Lancaster: Work Foundation.

Day, J. (2016.) Cyclogeography: Journeys of a London Bicycle Courier. London: Notting Hill Editions.

Forkert, K. (2017). Austerity as public mood. London: Rowman and Littlefield.

France, A. (2008). Being to Becoming: the importance of tackling youth poverty in transitions to adulthood. Social Policy and Society 7: 495-505.

Gale, T. (2005). Modernism, post-modernism and the decline of British seaside resorts as long holiday destinations. Tourism Geographies. 7, 86-112.

Giazitzoglu, A. (2014) Learning not to labour: a micro analysis of consensual male unemployment. International Journal of Sociology and Social Policy, 34, 334-47.

Grimshaw, D. \& Rubery, J. (2012). The end of the UK's liberal collectivist model. Cambridge Journal of Economics, 36, 105-126.

Hage, G. (2009). Waiting out the crisis: on stuckedness and governmentality pp 97-106 in Hage, G (ed) Waiting. Carlton Victoria: Melbourne University Press.

Hall, S-M. (2017). Personal, relational and intimate geographies of austerity, Area 49, 303-310.

Hall, S-M. (2019a). Everyday life in austerity: family, friends and intimate relations. Chichester: Wiley.

Hall, S-M. (2019b). A very personal crisis: family fragilities and everyday conjunctures within lived experiences of austerity. Transactions, Institute of British Geographers 44, 479-492.

Hardgrove, A., Rootham, E. \& McDowell, L. (2015). Precarious Lives, Precarious labour: Family Support and Young Men's Transitions to Work in the UK. Journal of Youth Studies, 18, 1057-76.

Harris, E., Nowicki, M. and Bricknell, K. (2018) On the edge in the impasse. Geoforum, 101, 156-164.

Hitchen, E. (2016) Living and feeling the austere. New Formations, 87, 102-118.

Hitchen, E. (2019). The affective life of austerity: uncanny atmospheres and paranoid temporalities. Social and Cultural Geography doi/org/10.1080/14649365.2019.1574884.

Horton, J. (2016). Anticipating service withdrawal: young people in spaces of neoliberalisation, austerity and economic crisis. Transactions, Institute of British Geographers, 41, 349-362.

Horton, J. \& Kraftl, P. (2009). What (else) matters? Policy contexts, emotional geographies. Environment and Planning A, 41, 2984-3002. 
House of Lords (2019). The future of seaside towns, report of a select committee on regenerating seaside towns and communities, Paper 320, London.

Hughes, G., Cooper, C., Gormally, S. and Rippingdale, J. (2014). The state of youth work in austerity England. Youth and Policy 113, 1-14.

Ilan, J. (2013). Street Social Capital in the Liquid City. Ethnography, 14, 3-24.

Ilan, J. (2015). Understanding Street Culture. London: Palgrave.

Jeffrey, C. (2010). Timepass: Youth, Class and the Politics of Waiting in India. Stanford: Stanford University Press.

Joelsson, T. (2015). 'Breaking bored' - negotiating spatial boredom and masculinity in the Volvo Greaser culture. Gender, Place and Culture, 22, 1252-1268.

Jones, O. (2011). Chavs: The Demonisation of the Working Class. London: Verso.

Joronen, M. (2017). Spaces of waiting: politics of precarious recognition in the occupied West Bank. Environment and Planning D: Society and Space, 35, 994-1011.

Jupp, E. (2017). Home space, gender and activism: the visible and invisible in austere times. Critical Social Policy, 37, 348-66.

Kentish, B. (2018). Theresa May declares 'austerity is over' The Independent 3 October, independent/co.uk/news/uk/politics (accessed 26 September 2019).

Littler, J. (2017). Against meritocracy: culture, power and the myths of mobility. London: Routledge.

McDowell, L. (2019) Looking for work: youth, masculinity and precarious employment in postmillennial England. Journal of Youth Studies, doi.org/10.1080.13676261.2019.164549.

McDowell, L. and Harris, A. (2018) Uruly bodies and dangerous spaces:masculinity and the geography of dreadful enclosuer. Urban Studies 56, 419-433.

Morrison, J. (2019) Scroungers: moral panics and media myths. London: Zed.

Nayak, A. (2006). Displaced masculinities: chavs, youth and class in the post-industrial city. Sociology, 40, 813-831.

Nixon, D. (2017). Yearning to labour? Working class men in post-industrial Britain. In Walker, C. and Roberts, S. Masculinity, Labour and Neoliberalism: Working Class Men in International Perspective. London: Palgrave Macmillan. 53-75.

O’Hara, P. (2014). Austerity bites. Bristol: Policy Press.

O'Neil, B. (2017). The space of boredom: homelessness in the slowing global order. Durham NC: Duke University Press.

Pettit, H. (2019) The cruelty of hope: emotional cultures of precarity in neoliberal Cairo. Environment and Planning D: Society and Space, 24, 733-752.

Power, A. \& Hall, E. (2018). Placing care in times of austerity. Social and Cultural Geography, 19, 303313. 
Prassl, J. (2018) Humans as a Service: the Promise and Perils of Work in the Gig Economy. Oxford: Oxford University Press.

Raynor, R. (2017). Dramatising austerity: holding a story together (and why it falls apart ...) Cultural Geographies, 24, 193-212.

Rickey, B. \& Houghton, J. (2009) Solving the riddle of the sands: regenerating England's seaside towns. Journal of Urban Regeneration and Renewal 3, 46-55.

Roberts, S. (2012). Boys will be boys ... won't they? Sociology, 47, 671-686.

Rootham, E. \& McDowell, L. (2017). Symbolic violence and cruel optimism: young men, un(der)employment and the Honda layoffs in Swindon in Harker, C, Skelton, T. and Horschelmann, C. (eds) Geographies of children and young people, vol 11, Springer, pp 1-17.

Runswick-Cole, K. and Goodley, D. (2015). Disability, austerity and cruel optimism in big society: resistance and 'the disability commons'. Canadian Journal of Disability Studies 4, 1-26.

Skeggs, B. (2004) Class, Self, Culture. London: Routledge.

Stenning, A. (2020). Feeling the squeeze: towards a psychosocial geography of austerity in low-to middle income families. Geoforum, 110, 200-210.

Strong, S. (2019) The vital politics of food banking: hunger, austerity, biopower Political Geography 75, doi.org/10.1016/j.polgeog.2019.102053.

Tyler, I. (2013). Revolting subjects: social abjection and resistance in neoliberal Britain. London: Zed.

Valentine, G. \& Harris, C. (2014). Strivers vs skivers: Class prejudice and the demonisation of dependency in everyday life. Geoforum, 53, 84-92.

Van Lanen, S. (2017). Living austerity urbanism:space-time expansion and deepening socio-spatial inequalities for disadvantaged urban youth in Ireland. Urban Geography, 38, 1603-1613.

Vasager, J. (2011). White working class culture can be the hardest to change, says school chief The Guardian 25 September.

Ward, K. (2015). Geographies of exclusion: seaside towns and houses in multiple occupancy. Journal of Rural Studies 37: 90-107.

Wilkinson, E. and Ortega-Alcazar, I. (2019). The right to be weary? Endurance and exhaustion in austere times. Transactions, Institute of British Geographers, 44, 155-167.

Williams, R. (1980). Culture and Materialism. London: Verso. 